UDK: $(31+33):(122+162.1)]: 314.15-053.81(497.6)$

Stručni rad

Primljeno: 10. 12. 2021.

Prihvaćeno za štampu: 13. 12. 2021.

\author{
Dr. sc. Hariz Šarić, red. prof. \\ Univerzitet u Tuzli - Filozofski fakultet \\ bariz.saric@unitz.ba
}

Dr. sc. Adisa Delić, red. prof.

Univerzitet u Tuzli - Ekonomski fakultet

adisa.delic@unitz.ba

\title{
SOCIJALNO-EKONOMSKI UZROCI I POSLJEDICE ODLASKA MLADIH IZ BOSNE I HERCEGOVINE
}

\section{Sažetak}

Istraživanje na temu „Socijalno-ekonomski urroci i posljedice odlaska mladih i₹ Bosne i Hercegovine "je imalo za cilj locirati, analiqirati i uturditi razloge, motive i povode qa napustanjem svoje domovine i odlaskom u druge destinacije na planeti Zemlji, s tě̌istem na socijalno-ekonomske posljedice tih odlazaka. Autori u radu tę̧išno analiziraju $i$ interpretiraju teorijske $i$ empirijske spoznaje o posljedicama koje urrokuju odlasci mladih iz Bosne i Hercegovine.

Polazecí od multidimenzionalnosti problema odlaska mladih iz. Bosne i Hercegovine koji iziskuje identifikaciju faktora na individualnom, porodicnom $i$ drustvenom nivou $i$ koji doprinose ovoj pojavi, istraživanje je fokusirano na individualne, endogene $i$ institucionalne faktore koji uzrokuju odlazak mladih iz Bosne $i$ Hercegovine, kao $i$ na socijalnoekonomske posljedice koje odlazak mladib nosi sa sobom.

U procesu istrǎ̌ivanja korištene su sljedeće metode i tehnike: analiza sadř̃aja, upitnik, intervju, studija slućaja, anketa i statisticke metoda. Za urorak je koristen stratifikovani uzorak vodeci računa o proporcionalnoj $i$ teritorijalnoj zastupljenosti mladih. Istrą̌ivanjem je obubvaćeno 600 mladih osoba koje su u periodu istrǎ̃ivanja imale od 18 do 29 godina.

Istraživanje provedeno u Bosni i Hercegovini u periodu 2019. godine i 2020. godine, pokazalo je da postoji više razloga, faktora i uzroka zasto mladi odlaze iz BiH te da 
su mladi ljudi, dobi od 18 do 29 godina, rastupljeni sa 69\% od ukupnog broja onih koji odlare, dok 31\% pripadaju ostalim starosnim skupinama.

$\mathrm{Na}$ temelju dobivenib requltata založili smo se za implikaciju sagledavanja negativnih utjecaja socijalnih faktora na socijalno-ekonomske urroke odlaska mladih iz Bosne $i$ Hercegovine.

Ključne riječi: socijalno-ekonomski uəroci, socijalno-ekonomske posljedice, mladi, faktori,

\section{UVOD $^{1}$}

Opredijeljenost autora za temu, koja se bavi socijalno-ekonomskim uzrocima i posljedicama odlaska mladih iz Bosne i Hercegovine, ima utemeljenje u činjenici da je 21. stoljeće, u koje smo ušli, stoljeće suočavanja s mnogim problemima mladih ljudi, tako is migracijama i odlaskom u druge države Evrope i svijeta. Kao socijalni fenomen, migracija je prisutna od davnina. Javlja se u svim društvima i neraskidivo je povezana s historijom ljudske vrste. Migracije su trajnije promjene mjesta prebivališta pojedinca ili društvene grupe koje mogu biti stalne ili privremene. Poseban oblik privremene migracije su sezonske migracije, u kojoj se odlazak i povratak migranata smjenjuje u godišnjim ciklusima. Generalno, na području Bosne i Hercegovine nedostaju naučna istraživanja koja se bave problemima odlaska mladih kao i socijalnih posljedica tih odlazaka. Specifičnost migracija u i iz Bosne i Hercegovine donijela je brojne izazove za učesnike socijalne i ekonomske politike. Predmetno istraživanje je posebno značajno s obzirom da se pretpostavlja da će se socio-ekonomska situacija u $\mathrm{BiH}$ pogoršati s obzirom na negativan uticaj zdravstveno-epidemiološke "krize" izazvane Covidom-19. Otuda se očekuje porast nezaposlenosti, posebno mladih, što će još značajnije aktualizirati njihov odlazak iz Bosne i Hercegovine.

Ovdje posebno naglašavamo potencijalni značaj rezultata istraživanja za Federaciju Bosne i Hercegovine, odnosno Bosne i Hercegovine, u

\footnotetext{
${ }^{1} \mathrm{U}$ radu je predstavljen dio istraživanja iz projekta (Socijalno-ekonomske posljedice odlaska mladih iz Bosne $i$ Hercegovine) koji je odobren na Univerzitetu u Tuzli, a rezultat internog poziva Univerziteta u Tuzli za finansiranje/sufinansiranje projekata iz oblasti nauke od značaja za Federaciju Bosne i Hercegovine u 2020. godini, u okviru programa 4: „Podrška istraživanju od značaja za Federaciju u 2020. godini““.
} 
skladu sa Strategijom razvoja Federacije Bosne i Hercegovine za period 2010-2020. Vizija i strateški ciljevi razvoja Federacije Bosne i Hercegovine predočavaju i promoviraju osnovne vrijednosti i dostignuća koja se žele postići strategijom razvoja u periodu 2010 2020. godina. Temelje se na evropskom putu razvoja i osnovnim nalazima situacione analize u Federaciji Bosne i Hercegovine, pri čemu je korištena metodologija susretnog planiranja, koja podrazumijeva određivanje razvojnih ciljeva, kako na osnovu već usvojenih strateških (srednjoročnih i dugoročnih) dokumenata na nivou Federacije Bosne i Hercegovine (pojedinačnih federalnih sektorskih strategija, strategije zapošljavanja i dr.) tako i na osnovu strateških dokumenata na nivou Bosne i Hercegovine. Za dostizanje željenog stanja, koje je opisano u viziji, identifikovani su i formulisani okvirni strateški ciljevi razvoja koji pružaju jasan odgovor na pitanje šta Federacija Bosne i Hercegovine želi i može postići u svom razvoju u pravcu optimiziranja rasta materijalne proizvodnje (nacionalnog dohotka) i životnog standarda stanovništva, te posebni prateći ciljevi razvoja koji su u funkciji realizacije općeg razvoja. Kao okvirni strateški ciljevi definirani su: (1) stabilni makroekonomski okvir, (2) konkurentnost i output, (3) javni sektor, (4) zaposlenost, (5) održivi rast i razvoj dok je šesti cilj (6) socijalna uključivost poseban dokument donesen na nivou Bosne i Hercegovine kao „Strategija socijalnog uključivanja”. U metodologiji definiranja ciljeva, poštovan je princip da ciljevi budu: (1) specifični, jasno definirani; (b) mjerljivi; (c) izvedivi, realno ostvarljivi; (d) relevantni izjavi vizije i (e) vremenski određeni. Strateški ciljevi su veoma globalni i predstavljaju odgovor na pitanje "šta želimo postići”, uzimajući u obzir naše resurse. Prioritetni ciljevi su prioriteti koji vode ostvarenju strateških ciljeva i približavanju viziji. Za definiranje svakog od specifičnih ciljeva se identificiraju realne mjere koje je potrebno poduzeti da bi se ostvarili prioriteti razvoja u datom vremenskom okviru. Mjere omogućuju da ciljevi budu vremenski i finansijski mjerljivi.

Danas se istraživanja razloga i motiva odlaska mladih temelje na proučavanju različitih faktora, vanjskih i unutrašnjih, u koje pored životnog ambijenta $\mathrm{i}$ faktora usidrenih u podsvijesti mladih, spadaju i društveni - koji su u kompleksu kulture, tradicije, socijalnih i ekonomskih uslova života itd. Savremena istraživanja kreću se u pravcu multifaktorijalnog pristupa ovom fenomenu. 
Sklop socijalnih, ekonomskih i šire društvenih, uz moguću dominaciju jednog faktora nad drugim, imaju značajnu ulogu u etiologiji ove pojave. Praćenje ove pojave na području Bosne i Hercegovine na dvadeset pet godina poslije rata predstavlja priliku da se određena istraživanja $\mathrm{i}$ rezultati uporede $\mathrm{s}$ rezultatima istraživanja prethodnih godina i ponude nove zajedničke činjenice.

Migracije predstavljaju kompleksan fenomen i nužno ga je interdisciplinarno istraživati $\mathrm{i}$ izučavati. Bosna i Hercegovina nije zaobiđena niti s lokalnim, niti regionalnim, a svjedočimo niti $\mathrm{s}$ globalnim migracijama. Migracije kao pojava su oduvijek tu i današnju bremenitost toj pojavi daju mediji i političari, odnosno diskurs kojim se koriste (Šarić, et al. 2020).

Nažalost, participacija mladih u bosanskohercegovačkom društvu je na nezavidnom nivou čak do stanja socijalne isključenosti. Socijalno uključivanje je definisano kao proces koji omogućava da oni koji su u riziku od siromaštva i društvene isključenosti, dobiju mogućnost $i$ sredstva koja su potrebna za puno učešće u ekonomskom, društvenom, kulturnom životu kao i postizanju životnog standarda i blagostanja koja se smatraju normalnim u društvu u kojem žive.

Važno je naglasiti i situaciju u kojoj nastaje ovaj rad tj. pokazatelji stanja u državi ponovno na površinu ,izbacuju“ nesposobnost i otvoreno zanemarivanje zaštite vlastitog domaćeg stanovništva, posebno posmatrajući zaštitu stanovištva kroz prizmu pandemije izazvane virusom Covid-19.

U sadašnjim promjenjljivim uslovima usljed pandemije Covid-19, tema iseljavanja i odlaska mladih postaje dramatično ozbiljna. Ukoliko se pristup ne promijeni, socijalni problemi će rasti i ne postoje budžeti koji će moći izdržati pritisak socijalnih potreba sve većeg dijela stanovništva (Papić, 2020). U okviru odlaska mladih zabilježeni su i brojni slučajevi djece bez pratnje roditelja i skrbnika, odnosno pojava razdvajanja obitelji, često prisutna u izbjegličkim tokovima.

U radu je dat akcenat na socijalno-ekonomske riziko-faktore odlaska mladih protkane krizom i problemima u odnosima, niskim ekonomskim statusom stanovništva, korupcijom, a sve to uz nezaobilazni osvrt na nefunkcionalnost i nebrigu državnih struktura i druge riziko-faktore. 
Ovim radom su obuhvaćeni gradovi (opštine), njih deset, iz cijele Bosne i Hercegovine za period 2019/2020. godina.

\section{Definicija pojmova}

Faktori rizika se najčešće dovode u vezu sa svim uslovima koji svojim prisustvom u životu ljudi povećavaju vjerovatnoću formiranja i ispoljavanja negativnog ponašanja. Prema Klaić B., (1978) - faktor (lat. facere) znači činiti, učiniti, (factor) činitelj, činilac, uzrok; pren. činitelj, činilac, okolnost, sila koja nešto stvara, činjenica. Faktori rizika (rizični faktori) su, u cjelini, karakteristike (od lične, porodične, obrazovne, poslovne, društvene ili kulturne prirode) čija prisutnost podiže vjerovatnost određenog fenomena u njegovom nastajanju (Popović-Ćitić, i Žunić-Pavlović, 2005). Faktori predstavljaju bilo kakve uzroke ili uslove koji posjeduje neku silu ili ta sila po sebi predstavlja bitan činilac javljanja nekog događaja ili promjene neke pojave. U psihologiji i socijalnom radu beskrajnu varijabilnost individualnih razlika moguće je opisati samo ako se poznaju dimenzije različitih faktora koji na njih utiču samostalno ili u kombinaciji (Vidanović, 2006).

Posljedica - poznata je kao posljedica koja proizlazi iz prethodnih okolnosti, djela ili činjenica. Riječ potječe od latinskog izraza consequentia, nastale iz korijena sa što znači ,zajedno" i Sequi, što znači ,ići”.

Migracija (lat. migratio "seoba", "putovanje") podrazumijeva odlazak osobe iz svoje zemlje porijekla i useljenje u drugu zemlju. Migracija podrazumijeva fizičko kretanje kroz prostor između dvije destinacije, pri čemu je važna udaljenost, vrijeme ili trajnost boravka u drugoj zemlji, stanovanje. Emigracija (lat. emigratio) iseljavanje, (ili: iseljenje) iz zemlje; sve izbjeglice iz neke države, emigrant (lat. emigrans) onaj koji se iseljava, iseljenik; onaj koji pobjegne iz domovine, osobito iz političkih ili dr. razloga, izbjeglica (Klaić, 1974).

Nezaposlenost podrazumijeva stanje u kojem se pojedinac kao radno sposobno lice ne može zaposliti primjereno svojim sposobnostima ili kvalifikacijama. U nezaposlene se, također, ubrajaju i svi članovi društva koji su djelimično zaposleni, ali njihova radna snaga nije u 
potpunosti iskorištena, ne rade puno radno vrijeme i nemaju konstantna redovna primanja za normalno izdržavanje.

Siromaštvo se najjednostavnije shvata i objašnjava kao neposjedovanje novca ili dovoljno novca za egzistenciju, te malo ili nedovoljno imovine. Siromaštvo se očituje na različite načine, među njima je nedostatak dohotka i zdravlja, nedostupnost ili ograničena dostupnost obrazovanja i drugih usluga, povećana smrtnost, beskućništvo i neodgovarajući stambeni uvjeti, društvena diskriminacija itd.

Koronavirusna bolest (COVID-19) je zarazna bolest uzrokovana virusom SARS-CoV-2. Stariji ljudi i oni s osnovnim zdravstvenim stanjima kao što su kardiovaskularne bolesti, dijabetes, kronične respiratorne bolesti ili rak imaju veću vjerojatnost da će razviti ozbiljne bolesti. Svako se može zaraziti od COVIDA-19 i ozbiljno se razboljeti ili umrijeti u bilo kojoj dobi (https://www.who.int/healthtopics/coronavirus \#tab=tab_1).

Mladi - Prema definiciji Ujedinjenih Nacija, mlada osoba je svaka osoba između 10 i 24 godine (www.un.org) i to po sljedećim kategorijama: adolescenti od 10 do 19 (rana faza 10-14, kasna faza 1519); omladina 15-24; mladi ljudi 10-24; iz čega proizilazi da jednu šestinu svjetskog stanovništva čine mladi. Savjet Evrope smatra osobu mladom do njene 30. godine, u Indoneziji do 40. godine, a u Bosni i Hercegovini $(\mathrm{BiH})$ se mladima smatraju osobe uzrasta između 14. i 29. godina, iako još zvanično nije donesena politika za mlade niti je usaglašeno koja je to granica godina koja će biti zajednička za cijelu Bosnu i Hercegovini. Međutim, po Zakonu o mladima Federacije Bosne i Hercegovine pod mladima se podrazumijevaju mladi ljudi od 15 do 29 godina i u ovom istraživanju smo se koristili ovim pojmom mladih. Mladi su takvi kakvo je društvo odraslih. Mladi nam poručuju da kad govorimo o njima, zapravo govorimo o sebi. Sve se više razvijaju znanosti koje se bave problemima mladih i mladima kao problemom.

Mobilnost - je širok pojam i uključuje i cirkulaciju stanovništva i migracije. Stoga, gore navedeni primjeri mogu se nazvati prostornom pokretljivošću stanovništva. Cirkulacija stanovništva obuhvaća brojne vrste kretanja stanovništva koje su uglavnom kratkoročne, ponavljaju se ili javljaju u ciklusima, ali ne postoji namjera za stalnim ili dugotrajnim preseljenjem. Stoga se sezonska kretanja radnika ili 
svakodnevni odlazak na posao u drugo mjesto smatra cirkulacijom, a ne migracijom. Dakle, osobe svakodnevno, sedmično, mjesečno, sezonski ili povremeno odlaze iz mjesta prebivališta i vraćaju se. Migracije su uži pojam od cirkulacije stanovništva, a odnose se na preseljenje iz jedne administrativne jedinice u drugu i uključuju trajnu promjenu prebivališta. Prema standardima Ujedinjenih naroda, trajna promjena mjesta boravka odnosi se na promjenu od godinu i više dana (Graovac Matassi, 2005).

Najvažniji uzroci migracija su demografski, ekonomski, politički i geografski, no, oni mogu i udružiti svoja djelovanja.

Migracije se često analiziraju u okviru ,push-pull modela”, koji obuhvaća „negativne” faktore, koji navode ljude da napuste svoju domovinu i ,pozitivne" faktore privlačenja, koji njihovu novu domovinu čine poželjnijim mjestom za život.

PUSH FAKTORI su: visoka stopa nezaposlenosti, siromaštvo, politička, rasna i etnička netrpeljivost, ratovi, prirodne katastrofe, dok su PULL FAKTORI: bolje prilike za zaposlenje i zaradu, bolji uvjeti života, politička, rasna i vjerska tolerancija, poštovanje ljudskih prava i politička sloboda. Tako se nezaustavljivo povećava statistički broj od dva miliona osoba koje žive u inozemstvu, a čije je porijeklo iz Bosne i Hercegovine, što je više od polovice stanovnika. Svi podaci upozoravaju na drastičan 'odljev mozgova' i odlazak mladih, a podaci Svjetskog ekonomskog foruma Globalne konkurentnosti u toj kategoriji smjestili su Bosnu i Hercegovinu na 131. mjesto od ukupno 133 države.

Prema podacima Unije za održivi povratak i integracije u Bosni i Hercegovini, državu je samo u zadnjih pet godina napustilo više od 170.000 ljudi. Inače, u Bosni i Hercegovini ne postoji zakonska obaveza odjave prebivališta, što znači da značajan broj onih koji napuštaju Bosnu i Hercegovinu zbog studiranja ili zaposlenja u inostranstvu ne odjavljuju svoje prebivalište. To znači da ne postoje tačni podaci o broju onih koji su Bosni i Hercegovini „okrenuli leđa“ i bolje sutra potražili uglavnom u zapadnoj Evropi. Osnovni razlog odlaska ljudi iz Bosne i Hercegovine, prije svega mladih, je nedostatak pravne države i mišljenje da u zemlji vlada opća nesigurnost. Na pitanje zašto napuštaju Bosnu i Hercegovinu, mladi najčešće navode: zbog nezaposlenosti, besperspektivnost, nezadovoljstvo obrazovnim i zdravstvenim 
sistemom, prevelika prisutnost korupcije.... Mladima treba graditi ambijent za ostanak u Bosni i Hercegovini, a ne da svoju perspektivu vide u drugim zemljama.

„Emigracija iz Bosne i Hercegovine je kontinuiran proces, a njeni glavni poslijeratni uzroci su socijalno-ekonomske prirode. $U$ pogledu nezaposlenosti u Bosni i Hercegovini, najveći problem je što je ona strukturne prirode - najveći udio predstavljaju osobe koje su nezaposlene više od godinu dana i čine $82 \%$ od ukupno nezaposlenih", navodi se u studiji ,Masovni odlazak mladih iz BiH: potraga za poslom ili bijeg od stvarnosti" koja je nastala saradnjom Centra za izborne studije i njemačke fondacije „Heinrich Böll".

U pomenutoj studiji se navodi da je ,zabrinjavajuća spremnost mladih ljudi na odlazak i njihova razočaranost situacijom u BiH". Analiza rezultata ove studije ukazuje na to da se naveći broj mladih ljudi, koji su zainteresirani za odlazak iz Bosne i Hercegovine u dobi od 21 godine - njih 24\%, izjasnilo da žele napustiti državu.

Procjenjuje se da oko $79 \%$ glasačkog tijela odlazi iz Bosne i Hercegovine, dok onih iz neglasačke populacije odlazi oko $3 \%$, što ukazuje na to da su ovi mladi ljudi prije zvaničnog odlaska pokušali doprinijeti poboljšanju sveukupne situacije u Bosni i Hercegovini, ali je na osnovu ovih podataka moguće zaključiti da vlasti nisu pokazale interes za ovom populacijom stanovništva.

Bosni i Hercegovini nedostaju strateška planiranja. Više od 20 godina se strateški veoma malo radi za mlade. Sada vidimo naplatu tog nerada. Svjesni smo da se nagomilani problemi ne mogu riješiti preko noći. Doduše, u posljednje vrijeme postoji određena volja da se nešto radi po pitanju kreiranja boljeg ambijenta za boravak mladih u Bosni i Hercegovini. Sarajevski, Unsko-sanski i Zeničko-dobojski kanton trenutno rade na tom pitanju. To je ohrabrujuća vijest i nada da ćemo konačno nešto početi raditi. Bez sistemskih rješenja i bez sistemskog pristupa ne možemo mnogo očekivati.

Odlaskom mladih, Bosna i Hercegovina gubi obrazovan, te politički postratno raštrkan i dezorijentisan mladi kadar. U Bosni i Hercegovini trenutno ne postoji nijedna institucija koja radi na donošenju strategije da se zaustavi odlazak mladih ljudi iz $\mathrm{BiH}$, uz izuzetak nekoliko „poslanika“ na nivou Bosne i Hercegovine koji se u svom radu zalažu 
za ovo pitanje. Zbog toga je neophodno podizanje svijesti o važnosti sprovođenja reforme obrazovanja i lobiranja za usklađivanje obrazovnog sistema $\mathrm{s}$ tržištem rada, podizanje svijesti o važnosti angažmana neke od nadležnih institucija ili komisija (po mogućnosti na državnom nivou) koja bi donijela hitnu strategiju o zaustavljanju/smanjenju broja mladih ljudi koji napuštaju Bosnu i Hercegovinu i promovisanje važnosti nezavisnosti medija kao iznimno važnog alata u kreiranju javnog mnijenja i uticaja, naročito na mlade ljude, prilikom formiranja njihovih mišljenja i stavova.

Mladi bi mogli biti aktivniji, ali im se ne pruža prostor na kojem će pokazati svoju inicijativu i želju za promjenama. Međutim, tim ljudima nedostaje podrška u svim segmentima i potrebno izvršiti promjene kako u oblasti obrazovanja tako i u oblasti zapošljavanja.

Nažalost, u Bosni i Hercegovini je situacija da se mladi boje nešto poduzeti na pokretanju, npr. vlastitog biznisa. Država nije ta koja im nudi dovoljno podsticaja, ne ohrabruje ih i mora se promijeniti ta praksa kako bi očekivali veću uključenost mladih u rješavanje ključnih pitanja.

Pored mladih, na potezu su i donosioci odluka u Bosni i Hercegovini, jer sve dok ,oni budu imali ovako nemaran odnos prema mladima $\mathrm{i}$ brojčanim pokazateljima o njihovom napuštanju $\mathrm{BiH}$, ovaj se trend neće moći zaustaviti, a dugoročno će, dodatno, doprinijeti nemogućnosti napretka i poboljšanja situacije u Bosni i Hercegovini, u svim segmentima. Jer, ako je budućnost na mladima, onda za $\mathrm{BiH}$ bez mladih nema ni budućnosti“. Nameće se niz pitanja koja čekaju odgovore. Kako Bosna i Hercegovina može pružiti mladim ljudima otvaranje radnih mjesta? Koja je to industrija koja će se razvijati u Bosni i Hercegovini? Može li Bosna i Hercegovina uskladiti obrazovni sistem i potrebe zapošljavanja?

\section{Nezaposlenost u Bosni i Hercegovini kao razlog odlaska mladih}

$\mathrm{BiH}$ je zemlja s jednom od najviših stopa nezaposlenosti. Trebaju se pokrenuti investicije, kreirati adekvatne ekonomske modele i politike. $\mathrm{BiH}$,nema“ u ovom trenutku socijalnu niti ekonomsku politiku.

Nema strategije da se spriječi odlazak mladih ljudi. Ovo što se događa u zadnjih godinu i pol je treći val koji se nije trebao dogoditi u tolikom 
broju. Šteta je golema, visoko obrazovanje je jako skupo, a onda mladi čovjek ode u drugu zemlju. Također, stanovništvo stari, premalo je novorođenih, posljedice će se jako osjetiti do 2030. godine. Odlaze najobrazovaniji. To će $\mathrm{BiH}$ dugoročno jako destabilizirati. Tu nema podataka o iseljavanju u EU i drugdje. Iza Drugog svjetskog rata su odlazili neobrazovani, početkom 90 -ih obrazovaniji, a sada odlaze najobrazovaniji. Mlade treba potaknuti da o svojoj karijeri razmišljaju puno ranije. U Njemačkoj je česta dualnost u školovanju. Njihovi učenici dio vremena provode na nastavi, a dosta vremena provode na praksi. Kod nas toga nema pa mladima nedostaju praktične vještine $\mathrm{i}$ iskustva. Niko ih ne potiče da razmišljaju o svojem školovanju. Sistem obrazovanja ne oblikuje ljude da budu spremni nakon fakulteta za svoj posao u struci (www.moj-posao.net).

Tri pravca djelovanja su moguća kako zaposliti mlade: samozapošljavanje, rad bez zasnivanja radnog odnosa (s ,pristojnom“ platom), te poslodavci koji mladom čovjeku do 30 godina daju ugovor na neodređeno vrijeme plaćat će manje obaveze (prema državi) pet godina.

Najveći broj građana ističe da je problem u ispolitiziranom pravosuđu, korupciji i nepotizmu koji prolaze bez kazne, a što je rak-rana našega društva. Imamo divnu zemlju, resurse i obrazovane ljude, ali sve nepovratno gubimo jer je stvorena besperspektivnost i apatija.

Nemamo dugoročne planove za razvoj, zapošljavaju se politički podobni umjesto sposobni, imamo političare kojima se imovinska kartica 'debelo' ne podudara sa stvarnim stanjem, radnike koji mjesecima rade bez plaće $i$ doprinosa $i$, unatoč svemu, teško nam je kazati „car je gol“. Ipak, mladi napuštaju sve bez "podizanja glasa" (https://www.dw.com/bs/bih-zemlja-staraca-i-sirotinje).

\section{Mladi u Bosni i Hercegovini - budućnost neizvjesna}

$\mathrm{U}$ BiH neće imati tko puniti mirovinski fond! "Naša budućnost bit će zemlja staraca bez mirovine i sa još više sirotinje". Način upravljanja u Bosni i Hercegovini bi se mogao nazvati, "političkom okupacijom u kojoj nema praktički ničeg ozbiljnijeg vezanog za struku, logiku, znanost te projiciranje i modeliranje budućnosti" (Domazet, A. et. al. 2020). 
Operativni plan izvršne vlasti nije postavljen sukladno programskim načelima i koncepcijama. Demografska problematika nije shvaćena kao strateško razvojno pitanje i naravno posljedice su nastavak svih negativnih trendova i pokazatelja do nivoa na kojem se već ugrožavaju osnovni sistemi u zemlji. Razlog? Politička sebičnost, interesna povezivanja, finansijsko-privredni pristup bez vrednovanja ljudskog potencijala i još puno toga. Problem zaista postaje pitanje nacionalne ili državne sigurnosti, odnosno jednostavnije rečeno, opstanka. Ko to na vrijeme shvati, sva će svoja politička djelovanja usmjeriti nacionalnim interesima i očuvanju najvećeg potencijala u svim društvima i prostorima - „ljudskog".

Manifestne posljedice su - sve brojnija starija populacija u zemlji. Činjenica da građani koji bi činili radnu snagu odlaze u velikom broju sigurno ima negativne efekte na ekonomiju ovdje - nedostatak radne snage i ograničeni potencijali talenta za pokretanje novih poslova $\mathrm{i}$ firmi. Također, zemlja gubi talente koji bi doprinijeli političkoj i kulturnoj obnovi, a država gubi kroz poreze koje bi ti ljudi uplatili. Još jedna nepovoljna posljedica je slom porodičnih struktura koje bi se uobičajeno brinule o starijima, i ovo već možemo primijetiti u nekim zajednicama u BiH. Jasno je da migracija prema vani predstavlja izazove koji će zahtijevati kreativna rješenja - bit će interesantno gledati šta će eventualno priključenje $\mathrm{BiH}$ EU donijeti migracijskoj slici, na pozitivan i negativan način.

Odlasci mladih iz Bosne i Hercegovine korespondiraju s povećanjem više dimenzija socijalne isključenosti ove starosne grupe, kao što su: stope nezaposlenosti i siromaštva, potrošnja, stanovanje, relativno opadanje prihoda zaposlenih, smanjena socijalna mobilnost, opadanje upotrebne vrijednosti diploma na tržištu rada, usamljenost i dosada.

\section{Metodologija istraživanja}

Predmet istraživanja su bile „Socijalno-ekonomski uzroci i posljedice odlaska mladih iz Bosne i Hercegovine“" u periodu od 2019. do 2020. godine.

Polazeći od multidimenzionalnosti problema koji iziskuje identifikaciju faktora na individualnom, porodičnom i društvenom nivou i koji doprinose pojavi odlaska mladih iz Bosne i Hercegovine istraživanje je 
bilo fokusirano na individualne, endogene i institucionalne faktore koji uzrokuju odlazak mladih i koje su to socijalne i ekonomske posljedice kao rezultat migracija.

Prostorno određenje predmeta istraživanja obuhvata područje Bosne i Hercegovine.

Vremensko određenje predmeta obuhvata period od 1. 1. 2020. do 31. 12. 2020. godine.

Cilj istraživanja bio je na kritički i komparativan način utvrditi i analizirati teorijska objašnjenja, rasprostranjenost, socijalnoekonomske faktore rizika odlaska mladih iz BiH. Multifaktorskim pristupom utvrditi obim, strukturu i dinamiku odlaska mladih iz $\mathrm{BiH}$ i socijalnoekonomske posljedice.

Hipoteza istraživanja - „Pretpostavlja se da odlazak mladih iz $\mathrm{BiH}$ postoji, da je uzrokovan nizom faktora $\mathrm{i}$ da ima trend rasta, te da poprima obilježja socijalnog problema i da ostavlja značajne negativne socijalno-ekonomske posljedice po bosanskohercegovačko društvo".

Metode istraživanja - Složenost predmeta i vremena istraživanja, definisani nivo naučnih saznanja i obim hipotetičkog sadržaja nametnuli su potrebu primjene različitih metoda i postupaka u procesu istraživanja socijalno-ekonomskih posljedica migracija mladih. To su: metoda ispitivanja, analize sadržaja, hipotetičko-deduktivne metode, statistička-općenaučna metoda. Korištena tehnika za prikupljanje podataka bio je intervju, dok je instrument istraživanja bio anketni upitnik - anketa.

Uzorak istraživanja - Odlučili smo da se za potrebe istraživanja izabere klaster uzorak, koji također predstavlja varijantu slučajnog uzorka s nešto nižom pouzdanošću (Biljan-August, M. i sar., 2009). Uzorak je koherentan s obzirom na poziciju ciljne populacije, tj. mladih osoba $u$ Bosni i Hercegovini, njih 600. Pri odabiru uzorka u obzir se uzela 141 općina (ukupno je 141 općina u $\mathrm{BiH}$ ), odnosno 141 klaster, među kojima je na slučajan način izabrano 5 općina s područja Federacije $\mathrm{BiH}, 4$ općine s područja Republike Srpske i Brčko distrikta. Izabrane općine su: Sarajevo - Stari grad, gradovi Mostar, Bihać, Zenica, Tuzla, Banja Luka, Bijeljina, Doboj i Trebinje. Iz svih općina po (60 ispitanika) kao i iz Brčko distrikta. 
Važno je imati u vidu da u Bosni i Hercegovini živi oko 570.000 mladih osoba, do 30 godina života, te ukazati i zainteresirati sve društvene nosioce, koji na određeni način pokazuju interes za oblast socijalne politike, da se uključe u njen koncept. Taj broj i predstavlja ukupni broj korisnika projekta.

Ograničenja u sprovođenju istraživanja se ogledaju u sljedećem. Na samom početku istraživanja, ispitanicima je jasno naglašena svrha istraživanja i zagarantovana anonimnost. Unatoč tome, postojala je mogućnost da će sudionici istraživanja simulirati odgovore. Rezultati ovog istraživanja na neki način mogu izgledati predvidivi, te da je stav o migracijama mladih osoba uglavnom negativan i da su posljedice katastrofalne.

Stoga, smisao istraživanja leži u rasvjetljavanju dilema koje postoje o tome - da li se kvaliteti života mladih osoba u Bosni i Hercegovini i posljedicama odlaska mladih iz BiH poklanja adekvatna pažnja.

Društvena opravdanost istraživanja proizilazi iz dvije osnove. Jedna je naučno saznanje o predmetu istraživanja, a druga je neposredna primjena naučnog saznanja do kojih se dođe, o neophodnosti lociranja i prevencije socijalnoekonomskih uzroka vezanih za migracije mladih osoba u Bosni i Hercegovini.

Činjenica je da su migracije mladih veoma aktuelan problem, ali još uvijek nedovoljno osviješten od strane društvene zajednice i njenih članova. Rezultati ovog istraživanja mogu poslužiti za podizanje kolektivne svijesti članova društvene zajednice o ovom problemu.

\section{Rezultati provedenog istraživanja}

\subsection{Pregled uzorka istraživanja}

Empirijski dio istraživanja obuhvatio je ukupno 60 gradova/općina na području $\mathrm{BiH}$, od toga 5 gradova/općina iz Federaciji Bosne i Hercegovine te 4 grada/općine iz RS-a i Brčko distrikta Bosne i Hercegovine. U svakom od gradova/općina uzet je klaster uzorak po 60 mladih, gdje imamo ukupan uzorak od $\mathrm{N}=600$ mladih. Od ukupnog broja ispitanika $\mathrm{N}=600$, mladi životne dobi 18-27 godina čine 414 ili 
$69 \%$ ukunog uzorka, dok mladi od 27 do 30 i više godina čine 186 ili $31 \%$ ukupnog uzorka istraživanja.

Ispitanici muškog spola čine 390 ili 72,5\% dok 210 ili 27,5\% čine ispitanice ženskog spola. Kada je u pitanju o bračni status ispitanika, 194 ili 32,3\% čine oženjeni/udati, dok 406 ili $67,6 \%$ čine neoženjeni/neudati ispitanici.

Kad je u pitanju zaposlenost, od ukupnog broja ispitanika $\mathrm{N}=600$, njih 286 ili 47,6\% bili su zaposleni. Od toga broja $\mathrm{N}=286$, na neodređeno vrijeme je zaposleno 134 ili 46,8\% ispitanika, dok je na određeno zaposleno 152 ili 53,1\% ispitanika.

Prosječna mjesečna zarada, dijela uzorka istraživanja, ispitanici koji su u radnom odnosu $\mathrm{N}=286$, najveći broj ispitanika 138 ili 48,2\% ostvaruje mjesečnu zaradu u visini od $501 \mathrm{KM}$ do $1000 \mathrm{KM}$. Prosječna mjesečna zarada u visini od $500 \mathrm{KM}$, ostvaruje ukupno 102 ili 35,6\% ispitanika. Ukupno 34 ili 11,8\% ispitanika ostvaruju prosječnu mjesečnu zaradu u visini 1000-2000 KM. Mjesečnu zaradu višu od 2001 KM ostvaruje 12 ili 4,1\% ispitanika, što je vidljivo u tabli br.1.

Tabela br. 1 Osnovni parametri uzorka istraživanja

\begin{tabular}{|c|c|c|c|c|}
\hline $\mathbf{R b}$ & Životna dob & f & $\%$ & $\mathbf{N}$ \\
\hline 1 & Od 18 do 27 godina & 414 & 69 & \multirow{9}{*}{600} \\
\hline 2 & od 27 do 30 godina & 186 & 31 & \\
\hline $\mathbf{R b}$ & Spol & $\mathbf{f}$ & $\%$ & \\
\hline 1 & Muškarci & 390 & 72,5 & \\
\hline 2 & Žene & 210 & 27,5 & \\
\hline $\mathbf{R b}$ & Bračni status & f & $\%$ & \\
\hline 1 & Oženjen/udata & 194 & 32,3 & \\
\hline 2 & Neoženjen/neudata & 406 & 67,6 & \\
\hline $\mathbf{R b}$ & Karakteristike zaposlenja & $\mathbf{f}$ & $\%$ & \\
\hline 1 & Zaposlen/a sam na neodređeno vrijeme & 134 & 46,8 & \multirow{7}{*}{286} \\
\hline 2 & Zaposlen/a sam na određeno vrijeme & 152 & 53,1 & \\
\hline $\mathbf{R b}$ & Prosječna mjesečna zarada & f & $\%$ & \\
\hline 1 & Do $500 \mathrm{KM}$ & 102 & 35,6 & \\
\hline 2 & Od 501 do $1000 \mathrm{KM}$ & 138 & 48,2 & \\
\hline 3 & Od 1001-2000 KM & 34 & 11,8 & \\
\hline 4 & Od 2001 i više & 12 & 4,1 & \\
\hline
\end{tabular}




\subsection{Odlazak mladih iz BiH zbog nemogućnosti pronalaska zaposlenja}

Rezultati istraživanja su pokazali da, od ukupnog broja ispitanika $\mathrm{N}=$ 600, najveći broj 366 ili 61\% ,potpuno se slaže“ da je razlog za napuštanje $\mathrm{BiH}$, nemogućnost pronalaska zaposlenja. Da se „slaže“ odgovorilo je 80 ili 13,3\% ispitanika, da se ,donekle slaže“ odgovrilo je 101 ili 16,8\% ispitanika.

Da mladi napuštaju BiH zbog nemogućnosti pronalska zaposlenja 46 ili $7,6 \%$ ispitanika se „ne slaže“, dok 7 ili 1,1\% ispitanika se ,uopšte se ne slaže" s tom tvrdnjom, što je vidljivo u tabeli br. 2.

Tabela br. 2 Odlazak mladih iz BiH-nemogućnosti pronalaska zaposlenja

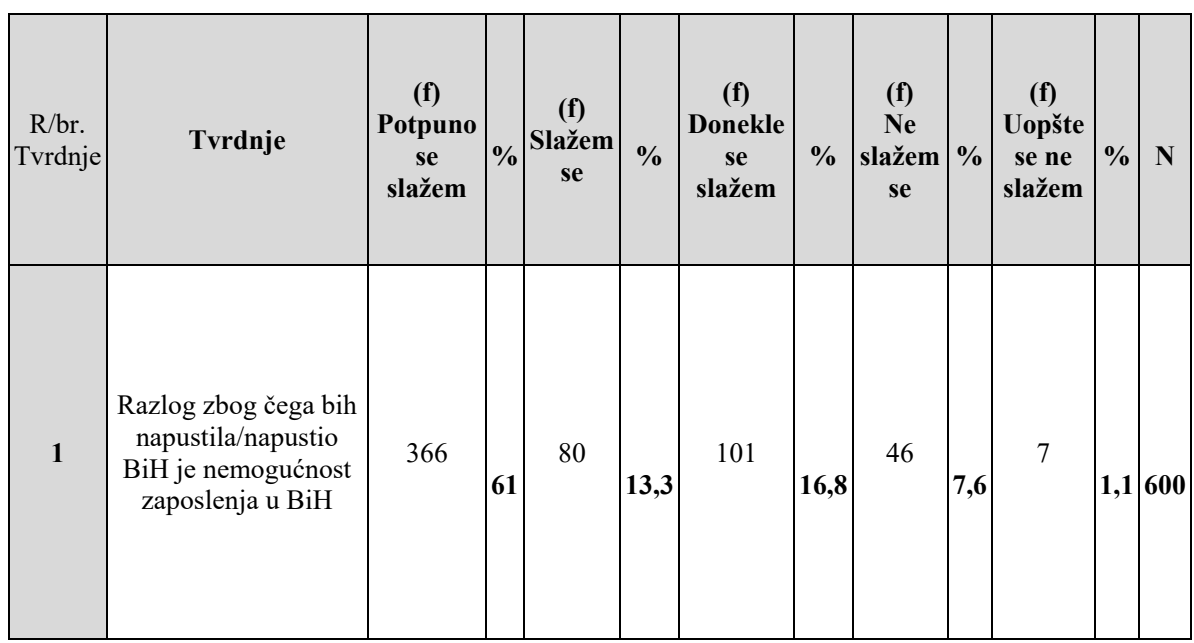

Pored toga, ispitanici navode da nije u pitanju samo posao nego i kvalitet samog radnog okruženja. Neuslovni radni prostori, minimalne plate, neuvezani radni staž, posao koji nije u struci, odnosno mladi većinom ne rade poslove za koje su se školovali. Ukoliko dobiju posao $\mathrm{u}$ struci to je na određeno vrijeme bez socijalno-ekonomske sigurnosti.

\subsection{Odlazak mladih iz BiH zbog nezadovoljstva kvalitetom radnog okruženja}

Od ukupnog broja ispitanika $\mathrm{N}=600$, najveći broj 409 ili 68,1\% „potpuno se slaže“ da je razlog za napuštanje $\mathrm{BiH}$, nezadovoljstvo kvalitetom radnog okruženja. Da se „slaže“ odgovorilo je 180 ili $30 \%$ ispitanika, da se „donekle slaže“ odgovrilo je 11 ili 1,8\% ispitanika. Niti 
jedan ispitanik se nije izjasnio da se „ne slaže“ $\mathrm{s}$ tom tvrdnjom, jer kako navode nije u pitanju samo posao nego i okolnosti u kojima se nalaze, od radnog okruženja do selektivnog tumačenja Radnog prava. Opisano je na način da poslodavci selektivno tumače zakone, to jeste, iz Zakona uzimaju samo ono što njima odgovara, dok koristi iz Radnog prava koje slijede zaposlenicima se jednostavno ne provode, što je vidljivo u tabeli br. 3 .

Tabela br. 3 Odlazak mladih iz BiH - nezadovoljstvo kvalitetom radnog okruženja

\begin{tabular}{|c|c|c|c|c|c|c|c|c|c|c|c|c|}
\hline $\begin{array}{c}\text { R/br. } \\
\text { tvrdnje }\end{array}$ & Tvrdnje & $\begin{array}{c}\text { (f) } \\
\text { Potpuno } \\
\text { se } \\
\text { slažem }\end{array}$ & $\%$ & $\begin{array}{c}\text { (f) } \\
\text { Slažem } \\
\text { se }\end{array}$ & $\begin{array}{c}\text { (f) } \\
\text { Donekle } \\
\text { se } \\
\text { slažem }\end{array}$ & $\begin{array}{c}\text { (f) } \\
\text { Ne } \\
\text { slažem } \\
\text { se }\end{array}$ & $\begin{array}{c}\text { (f) } \\
\text { Uopšte } \\
\text { se ne } \\
\text { slažem }\end{array}$ & $\%$ & $\mathbf{N}$ \\
$\mathbf{1}$ & $\begin{array}{l}\text { Razlog zbog čega } \\
\text { bih } \\
\text { napustila/napustio } \\
\text { BiH je } \\
\text { nezadovljstvo } \\
\text { kvalitetom radnog } \\
\text { okruženja }\end{array}$ & 409 & $\mathbf{6 8 , 1}$ & 180 & $\mathbf{3 0}$ & 11 & $\mathbf{1 , 8}$ & 0 & $\mathbf{0}$ & 0 & $\mathbf{0}$ & $\mathbf{6 0 0}$ \\
\hline
\end{tabular}

Ispitanici su naveli i to, da dok se školuju, nemaju mogućnost obavljanja prakse, učešća u naučnim radovima, dodatnim neformalnim edukacijama, sve što imaju vani. S druge strane školovanje nije besplatno u BiH i predstavlja veliki teret za roditelje mladih ljudi koji studiraju van svog grada. Korupcija i nepotizam unutar obrazovnog sistema je dodatni motiv za odlazak van granica BiH. Mladi posebno ističu problem ,,serijskog štampanja“ diploma i proizvođenja kadra, s fokusom na visoku stručnu spremu. Pored toga, ističu da ne mogu dobiti posao u struci i po 10 godina nakon završetka fakulteta.

\subsection{Odlazak mladih iz $\mathrm{BiH}$, nezadovljstvo zbog neuređenosti političko-pravnog sistema}

Prema dobijenim rezultatima istraživanja, zasigurno najveći postotak potvrdnih odgovora, u smislu, da se najveći broj ispitanika slaže s tvrdnjama u pitanju, jeste oblast političko-pravnog sistema. 
Tabela br. 4 Odlazak mladih iz BiH - nezadovljstvo zbog neuređenosti političko-pravnog sistema

\begin{tabular}{|c|c|c|c|c|c|c|c|c|c|c|c|c|}
\hline $\begin{array}{l}\text { R/br. } \\
\text { Tvrdnje }\end{array}$ & Tvrdnje & \begin{tabular}{|c} 
(f) \\
Potpuno \\
se \\
slažem \\
\end{tabular} & $\%$ & $\begin{array}{c}\text { (f) } \\
\text { Slažem } \\
\text { se }\end{array}$ & $\%$ & \begin{tabular}{|c|} 
(f) \\
Donekle \\
se \\
slažem \\
\end{tabular} & $\%$ & \begin{tabular}{|c|} 
(f) \\
Ne \\
slažem \\
se \\
\end{tabular} & $\%$ & $\begin{array}{c}\text { (f) } \\
\text { Uopšte } \\
\text { se ne } \\
\text { slažem }\end{array}$ & $\%$ & $\mathbf{N}$ \\
\hline 1 & $\begin{array}{l}\text { Razlog zbog čega } \\
\text { bih } \\
\text { napustila/napustio } \\
\text { BiH je } \\
\text { nezadovljstvo zbog } \\
\text { neuređenosti } \\
\text { političko-pravnog } \\
\text { sistema }\end{array}$ & 512 & 85,3 & 81 & 13,5 & 0 & 0 & 7 & 1,1 & 0 & $\mathbf{0}$ & 600 \\
\hline
\end{tabular}

Od ukupnog broja ispitanika $\mathrm{N}=600$, najveći broj 512 ili 85,3\% „potpuno se slaže“ da je razlog za napuštanje $\mathrm{BiH}$, neuređenost političko-pravnog sistema. Da se ,slaže“ odgovorilo je 81 ili 13,5\% ispitanika, da se „donekle slaže“ kao i da se „uopšte se ne slaže“ nije bilo odgovora. Da mladi napuštaju $\mathrm{BiH}$ zbog neuređenosti političkopravnog sistema 7 ili 1,1\% ispitanika se ,ne slaže“, s tom tvrdnjom, što je vidljivo u tabeli br. 4.

Izjava: „Nije u pitanju više ni novac, ni posao koliko više ne možemo da podnesemo ovaj odnos države prema nama mladima, više ne možeš ni kao pripravnik raditi, nego radim ko volonter/pripravnik da me ne bi platili slučajno... “ (E. Ž. 24 godine).

\subsection{Odlazak mladih iz $\mathrm{BiH}$, nezadovljstvo zbog korupcije i nepotizma}

Rezultati istraživanja su pokazali da, od ukupnog broja ispitanika $\mathrm{N}=$ 600, najveći broj 501 ili 83,5\% ,potpuno se slaže“ da je razlog za napuštanje $\mathrm{BiH}$, nezadovljstvo zbog korupcije i nepotizma. Da se „slaže“ odgovorilo je 87 ili 14,5\% ispitanika, da se „donekle slaže“ odgovrilo je 10 ili 1,6\% ispitanika.

Da mladi napuštaju BiH zbog nezadovljstvo zbog korupcije i nepotizma 2 ili $0,3 \%$ ispitanika se „ne slaže“, dok niko od ispitanika nije odgovorio da ,uopšte se ne slaže“ sa tom tvrdnjom, što je vidljivo u tabeli br. 5. 
Tabela br. 5 Odlazak mladih iz BiH - nezadovljstvo zbog korupcije $i$ nepotizma

\begin{tabular}{|c|c|c|c|c|c|c|c|c|c|c|c|c|}
\hline $\begin{array}{l}\mathrm{R} / \mathrm{br} \text {. } \\
\text { tvrdnje }\end{array}$ & Tvrdnje & $\begin{array}{c}\text { (f) } \\
\text { Potpuno } \\
\text { se slažem }\end{array}$ & $\%$ & $\begin{array}{l}\text { (f) } \\
\text { Slažem } \\
\text { se }\end{array}$ & $\%$ & $\begin{array}{c}(f) \\
\text { Donekle } \\
\text { se slažem }\end{array}$ & $\%$ & $\begin{array}{l}\text { (f) } \\
\mathrm{Ne} \\
\text { slažem } \\
\text { se }\end{array}$ & $\%$ & $\begin{array}{l}\text { (f) } \\
\text { Uopšte } \\
\text { se ne } \\
\text { slažem }\end{array}$ & $\%$ & $\mathbf{N}$ \\
\hline 1 & $\begin{array}{l}\text { Razlog zbog čega bih } \\
\text { napustila/napustio BiH je } \\
\text { nezadovljstvo zbog } \\
\text { korupcije i nepotizma }\end{array}$ & 501 & 83,5 & 87 & 14,5 & 10 & 1,6 & 2 & 0,3 & 0 & 0 & 600 \\
\hline
\end{tabular}

Izjava: „Bila sam i u stranci, radila za njih, umirala..., da bi dobila bilo kakav posao. Naravno nakon izbora posao nisam dobila, aplicirala sam na milion radnih mjesta, što u struci što van struke, jednostavno više nemam ni snage ni novca da tražim posao. Upisala sam kurs njemačkog jezika i odo sljedeće godine raditi ko njegovateljica..." (A. Dž. 28 godina).

\subsection{Odlazak mladih iz $\mathrm{BiH}$, općenitog zbog nezadovoljstva životom}

Tabela br. 6 Odlazak mladih iz BiH - općenito nezadovoljsto životom

\begin{tabular}{|c|c|c|c|c|c|c|c|c|c|c|c|c|}
\hline $\begin{array}{l}\text { R/br. } \\
\text { Tvrdnje }\end{array}$ & Tvrdnje & $\begin{array}{c}\text { (f) } \\
\text { Potpuno } \\
\text { se } \\
\text { slažem } \\
\end{array}$ & $\%$ & $\begin{array}{l}(\mathbf{f}) \\
\text { Slažem } \\
\text { se }\end{array}$ & $\%$ & $\begin{array}{c}\text { (f) } \\
\text { Donekle } \\
\text { se } \\
\text { slažem } \\
\end{array}$ & $\%$ & $\begin{array}{c}\text { (f) } \\
\text { Ne } \\
\text { slažem } \\
\text { se } \\
\end{array}$ & $\%$ & $\begin{array}{c}\text { (f) } \\
\text { Uopšte } \\
\text { se ne } \\
\text { slažem } \\
\end{array}$ & $\%$ & $\mathbf{N}$ \\
\hline 1 & $\begin{array}{l}\text { Razlog zbog čega } \\
\text { bih } \\
\text { napustila/napustio } \\
\text { BiH je zbog } \\
\text { općenitog } \\
\text { nezadovoljstva } \\
\text { životom }\end{array}$ & 412 & 68,6 & 171 & 28,5 & 2 & 0,3 & 11 & 1,8 & 4 & 0,6 & 600 \\
\hline
\end{tabular}

Prema dobijenim rezultatima istraživanja, najveći broj ispitanika se slaže s tvrdnjama po pitanju oblasti političko-pravnog sistema. Kad je u pitanju općenito nezadovoljsto životom, od ukupnog broja ispitanika $\mathrm{N}=600$, najveći broj 412 ili $68,6 \%$,potpuno se slaže“ da je to razlog za napuštanje $\mathrm{BiH}$. Da se ,slaže“ odgovorilo je 171 ili 28,5\% ispitanika, da se ,donekle slaže“ odgovorilo je 2 ili $0,3 \%$ ispitanika, 11 ili 1,8\% ispitanika se „ne slaže“ s tom tvrdnjom, te da „uopšte se ne slaže“ odgovorilo je 4 ili $0,6 \%$ ispitanika.

Nezadovoljstvo među mladima izaziva manifestacija sveukupnog stanja u državi što su izrazili u mnoštvu pisanih izjava kao naprimjer:

Izjava: „Kako da dobijem motiv za život kada pogledam ovo stanje u državi, naše političare koji zarađuju po $7000 \mathrm{KM}$ mjesečno, ne rade, ne dolaze na posao, država blokirana, ljudi nam se smiju. Sve to toliko utiče na nas mlade da jednostavno ne želimo da ulažemo sebe u ovu 
državu, jedini spas vidimo vani gdje će nas neko cijeniti zbog onoga što smo i platiti za ono koliko radimo... “(P. M. 30 godina).

Istraživanje je pokazalo razlike između zakonodavne regulative i stvarnog stanja kvalitete života mladih osoba u Bosni i Hercegovini. Zakon o mladima FBiH je usvojen prije više od 10 godina, još uvijek nije urađena Strategija za mlade niti bilo kakav akcioni plan koji će biti usmjeren na mlade. Pojedine općine i gradovi su napravili vlastite Strategije za mlade, ali njihova provedba izostaje. Većina tih strategija nema akcione planove provedbe istih niti planirane budžete provedbe, gdje bi se odredile prioritetne mjere koje je neophodno odmah implementirati poput zaustavljanja odlaska mladih iz $\mathrm{BiH}$.

Da mlade osobe nemaju adekvatne uvjete za stanovanje, te da mladi koji nemaju svoj stan, nemaju ni kvalitetan život. Programi za stambeno zbrinjavanje mladih bračnih partnera do 35 godina života su kreirani na takav način da uslove za apliciranje mogu ispuniti samo mladi bračni patneri koji su već stambeno zbrinuti i ekonomski stabilni (da imaju posao, da su kreditno sposobni i da su već kupili stan). Dok s druge strane mladi koji nemaju adekvatne uvjete za stanovanje, koji su nezaposleni, ne ispunjavaju uslove za apliciranje na takve javne pozive. Svoju energiju i vrijeme radije ulažu u sezonske poslove van granica $\mathrm{BiH}$, „sakupljajući“ novac za obezbjeđivanje minimalnih stambenih uvjeta.

Mladi nisu zadovoljni organizacijom slobodnog vremena i izjavljuju da su isključeni iz društva. „Svoje slobodno vrijeme popunjavanju aktivnostima na društvenim mrežama, kao najaktivniji korisnici društvenih mreža najčešće koriste Instagram $(80,4 \%)$, potom YouTube $(69,3 \%)$ i Facebook (67,3\%). Posljedice Covida-19, su dodatno uticale na povlačenje istih $u$ sebe, bez mogućnosti druženja, izlazaka i ukuljučivanja u svakodnevne društvene tokove“ (Istraživanje o položaju mladih u BiH - KULT, 2021).

Veliki broj mladih ljudi je izgubilo nadu u sport (kao vid provođenja slobodnog vremena), zbog velikog prisustva korupcije u ,vodama sporta", gdje kvalitet sportiste nije opredjeljujući za uspjeh. Dugogodišnje ulaganje u sport na vrhuncu karijere završava razočarenjem jer u $\mathrm{BiH}$ da bi bio uspješan sportista, treba imati novac ili dobre veze. 
Kada je volontiranje u pitanju i angažman u nevladinim organizacijama, ispitanici su naveli: navedeno se pretvorilo u radnu eksploataciju mladih od strane nevladinih organizacija. Sve više mladih shvata „pozadine“" volonterskog rada te isti zaobilazi u ,širokom luku“.

\subsection{Odlazak mladih iz $\mathrm{BiH}$, socijalno-ekonomske posljedice}

Posljedice iseljavanja mogu se klasificirati kao pozitivne i negativne, te kratkoročne i dugoročne. Prividno pozitivna posljedica može biti smanjenje opće stope nezaposlenosti. Naziva se prividnom jer iseljavanje nema utjecaja ili je utjecaj beznačajan na smanjenje nezaposlenosti u zemljama porijekla. Stoga, gledajući na smanjenje opće stope nezaposlenosti kao na pozitivnu posljedicu iseljavanja, treba imati na umu da se iseljavanjem istovremeno smanjuje i ukupno radno sposobno stanovništvo te da rastuća negativna selekcija postaje česta nuspojava. Osim navedene kratkoročne 'pozitivne' posljedice snižavanja opće stope nezaposlenosti, odljev mozgova ima za srednjoročnu i dugoročnu negativnu posljedicu "moguće poremećaje na tržištu rada, te destabilizaciju zdravstvenog, socijalnog i mirovinskog sustava, zbog očekivanog gubitka fiskalne i porezne baze“" (Troskot, Z. i sur., 2019).

Prema istom autoru, dugoročno gledano, odljev mozgova može imati za posljedicu i demografski slom države s obzirom na to da gubitkom visokoobrazovanih, najčešće mladih stanovnika, država ostaje bez značajnog dijela populacije u reproduktivnoj dobi. Nadalje, odlazak visokokvalificiranih za državu znači gubitak ljudskog kapitala, direktno utječe na čitavu znanstvenu i obrazovnu zajednicu, dovodi u pitanje vrijednosti čitavog društva te stvara negativno i nesigurno ozračje za buduće generacije i njihov doprinos društvu. Odljev mozgova znači i gubitak finansijskih resursa jer država odlaskom visokoobrazovanih pojedinaca gubi novac koji je uložila u njihovo obrazovanje, kao i budući prihod koji su oni mogli ostvariti da su svoju karijeru odlučili razvijati u zemlji porijekla. U nedostatku inovacija i međunarodno prepoznatljivih istraživačkih projekata, odljev mozgova dovodi i do tehnološkog zaostajanja zemlje.

U konačnici, iako odlazak visokoobrazovanih može ozbiljno poljuljati temelje obrazovnog sistema, ne treba zanemariti da ti isti pojedinci "koji su preseljenjem u inozemstvo promijenili referentni okvir svog 
razvoja te stekli nova znanja, vještine, poznanstva i finansijske resurse, mogu u slučaju povratka u matičnu zemlju pomoći društvenom i privrednom razvoju čak i više nego oni koji su, iako imaju mogućnost oblikovati novi život u inozemstvu, odlučili ostati u matičnoj zemlji." Iako je primarno negativna pojava za zemlju iseljavanja, odljev mozgova može imati i pozitivne privredne učinke. Novčane doznake često se percipiraju kroz njihov pozitivan privredni učinak, no potrebno je imati u vidu nekoliko bitnih spoznaja (Troskot, Z. i sur., 2019).

Drugi potencijalni pozitivan privredni učinak iseljavanja visokokvalificirane radne snage može biti razvijanje ljudskog potencijala prikupljanje iskustva stečenog $u$ inozemstvu pod pretpostavkom kružne migracije i primjene stečenog znanja u državi porijekla. Nadalje, pojedinac može doprinijeti i investicijama u privredi zemlje porijekla.

Kao posljedica emigracije (naročito u ratnom i postratnom periodu), Bosanci i Hercegovci su danas evidentirani stanovnici u 88 zemalja svijeta. Isto tako je važno naglasiti da Bosna i Hercegovina nije jedina država koja se susreće s problemom odlaska mladih, naprotiv spada u grupu preko sto država koje imaju sličnu sudbinu i gdje je izražen ovaj fenomen. Rogobatan državni ustroj, kako ga neki nazivaju „dejtonska luđačka košulja" itekako ometa funkcionisanje države $\mathrm{BiH}$ i posljedično kreira ambijent iz kojeg mladi žele otići. Nažalost, nedovoljno se čini na odgoju mladih u smislu jačanja patriotizma $\mathrm{i}$ ljubavi prema svojoj domovini Bosni i Hercegovini. Doprinos ,ostanku mladih" mogla bi dati i vjerska zajednica, imajući u vidu da je među mladima i jedan broj vjerskih službenika koji svoju budućnost vide van $\mathrm{BiH}$.

Podaci nevladinih organizacija o odlasku mladih iz BiH u većini država bi bili alarm za uzbunu, no tako nešto nije se desilo u BiH. Donosioci odluka još uvijek nisu pronašli mehanizam kako zadržati svoje građane da ne odlaze. 
Tabela br. 7 Odlazak mladih iz BiH - socijalno-ekonomske posljedice

\begin{tabular}{|c|c|c|c|c|c|c|c|c|c|c|c|c|}
\hline $\mathrm{R} / \mathrm{br}$. & Tvrdnje & \begin{tabular}{|c|} 
(f) \\
Potpuno \\
se \\
slažem
\end{tabular} & $\%$ & $\begin{array}{l}(f) \\
\text { Slažem } \\
\text { se }\end{array}$ & $\%$ & \begin{tabular}{|c|}
$(f)$ \\
Donekle \\
se \\
slažem
\end{tabular} & $\%$ & $\begin{array}{c}\text { (f) } \\
\text { Ne } \\
\text { slažem } \\
\text { se }\end{array}$ & $\%$ & \begin{tabular}{|c} 
(f) \\
Uopšte \\
se ne \\
slažem
\end{tabular} & $\%$ & $\mathbf{N}$ \\
\hline 1 & $\begin{array}{l}\text { Kolaps } \\
\text { penzionog } \\
\text { fonda }\end{array}$ & 401 & 66,8 & 197 & 32,8 & 2 & 0,3 & 0 & $\mathbf{0}$ & 0 & 0 & 600 \\
\hline 2 & \begin{tabular}{|l|} 
Nedostatak \\
radne snage i \\
ograničeni \\
potencijali \\
talenta za \\
pokretanje \\
novih poslova \\
i firmi \\
\end{tabular} & 329 & 54,8 & 180 & 30 & 24 & 4 & 67 & 11,1 & 0 & 0 & \\
\hline 3 & $\begin{array}{l}\text { Razdvajanje } \\
\text { porodice - } \\
\text { slom } \\
\text { porodičnih } \\
\text { struktura } \\
\end{array}$ & 428 & 71,3 & 172 & 28,6 & 0 & 0 & 0 & o & 0 & 0 & \\
\hline 4 & $\begin{array}{l}\text { Urušavanje } \\
\text { zdravstvenog, } \\
\text { obrazovnog } \mathrm{i} \\
\text { socijalnog } \\
\text { sistema }\end{array}$ & 192 & 32 & 152 & 25,3 & 116 & 19,3 & 126 & 21 & 14 & 2,3 & \\
\hline 5 & $\begin{array}{l}\text { Povećana } \\
\text { stopa } \\
\text { ispoljavanja } \\
\text { socijalno- } \\
\text { patoloških } \\
\text { oblika } \\
\text { ponašanja } \\
\text { (alkohol, } \\
\text { droga, kocka, } \\
\text { kriminal) } \\
\end{array}$ & 291 & 48,5 & 111 & 18,5 & 118 & 19,6 & 80 & 13,3 & 0 & 0 & \\
\hline
\end{tabular}

Istraživanje je pokazalo je da su najvidljivije posljedice masovnog odlaska mladih iz BiH: kolapas Penzionog fonda; nedostatak radne snage i ograničeni potencijali talenta za pokretanje novih poslova $\mathrm{i}$ firmi; razdvajanje porodice - slom porodičnih struktura; urušavanje zdravstvenog, obrazovnog i socijalnog sistema; povećana stopa ispoljavanja socijalno - patoloških oblika ponašanja (alkohol, droga, kocka, kriminal).

$\mathrm{Na}$ tvrdnju, da odlazak mladih iz $\mathrm{BiH}$ može dovesti do kolapsa Penzionog fonda, najveći broj 401 ili 66,8\% ispitanika navodi izraz „potpuno se slaže“. Da se ,slaže“ odgovorilo je 197 ili 32,8\% 
ispitanika, da se „donekle slaže“ odgovorilo je 2 ili 0,3\% ispitanika. Niti jedan ispitanik se nije izjasnio da se ,ne slaže“ i oblik ,uopšte se ne slaže" sa tom tvrdnjom. Veliki postotak mladih je svjestan posljedica donošenja takve odluke i odlaska iz $\mathrm{BiH}$, međutim nije primijećena doza empatije od strane ispitanika prema građanima koji ostaju u $\mathrm{BiH}$, posebno prema populaciji koja se nalazi u trećoj starosnoj dobi. Mladi su okrenuti sebi i svojim planovima, navodeći da će za svoje roditelje obezbijediti sve što im bude trebalo, ali da ne mogu voditi računa o državnim kasama, jer iz tih državnih kasa nisu dobili ništa, te zbog toga i napuštaju $\mathrm{BiH}$.

Kada je riječ o posljedicama koje su naslonjene na mogući nedostatak radne snage i ograničeni potencijali talenta za pokretanje novih poslova i firmi, odgovori ispitanika su bili podjeljeni. Najveći broj 329 ili 54,8\% ispitanika navodi izraz, ,potpuno se slaže“" $\mathrm{s}$ tom tvrdnjom, da se ,slaže“ odgovorilo je 180 ili 30\% ispitanika, da se „donekle slaže“ odgovorilo je 24 ili 4\% ispitanika, te da se „ne slaže“" odgovorilo je 67 ili 11,1\% ispitanika. Dio ispitanika koji se ne slaže s navedenom tvrdnjom o posljedicama koje ostavlja odlazak mladih iz BiH iz razloga, što navode da mladi nisu presudni u otvaranju i pokretanju firmi i biznisa te da nisu „,najpoželjnija“ radna snaga u $\mathrm{BiH}$. Određeni ispitanici tvrde da će čak biti olakšano pokretanje novih biznisa, jer će država shvatiti da mora obezbijediti veće olakšice pri samom osnivanju firimi potom obezbijediti poticaje za iste, jer će shvatiti da državnu kasu nema ko puniti. S druge strane na teritoriju $\mathrm{BiH}$ se već počelo uvoziti jeftina radna snaga iz zemalja Azije, poput Vijetnamaca, Tajlanđana, Indijaca i dr. Nekoliko prijedloga od strane ispitanika se odnosilo na zadržavanje migranta u $\mathrm{BiH}$ i kreiranje „kordona“ jeftine radne snage.

Rezultati istraživanja o posljedicama koje se odnose na razdvajanje porodice - slom porodičnih struktura, jasno pokazuju, da su odgovori homogeni u odnosu na ostale tvrdnje. Najveći broj 428 ili 71,3\% ispitanika navodi oblik ,potpuno se slaže“"s tom tvrdnjom, da se „slaže“ odgovorilo je 172 ili 28,6\% ispitanika. Napuštanje svoje države ujedno znači i razdvajanje od porodice i familije, što zasigurno ostavlja duboke poljedice i na mladu osobu koja odlazi iz $\mathrm{BiH}$, a tako i na dio porodice koji ostaje u BiH. Posebno je izražen problem kod mladih bračnih parova gdje jedan bračni partner odlazi van $\mathrm{BiH}$ na određeni ,probni““ period, gdje dolazi do razora unutrašnjih porodičnih odnosa, 
nerazumijevanja, ljubomore pa i do trajno poremećenih odnosa koje rezultiraju raskidom bračne zajednice.

Na tvrdnju da kao jednu od možda i najtežih posljedica koja se odnosi na urušavanje tri ,glavna stuba društava“, zdravstvenog, obrazovnog i socijalnog sistema, najveći broj 192 ili 32\% ispitanika navodi ,potpuno se slaže“ s tom tvrdnjom, da se "slaže“ odgovorilo je 152 ili $25,3 \%$ ispitanika, da se „donekle slaže“" odgovorilo je 116 ili 19,3\% ispitanika, te da se „ne slaže“ odgovorilo je 126 ili 21\% ispitanika i 14 ili 2,3\% ispitanika se ,uopšte ne slaže“ s tom tvrdnjom. Dio ispitanika, koji se ne slaže s navednom tvrdnjom o posljedicama koje su usmjerene na urušavanje pomenuta tri stuba društva, navode da država ima dovoljno novca te da uvijek postoji mogućnost zaduživanja od MMF-a i na taj način sanira pomenute posljedice.

Posljedice koje su usmjerene direktno na stanovnike $\mathrm{BiH}$, a odnose se na povećanu stopu ispoljavanja socijalno-patoloških oblika ponašanja (alkohol, droga, kocka, kriminal), najveći broj 291 ili 48,5\% ispitanika navodi oblik ,potpuno se slaže“ $\mathrm{s}$ tom tvrdnjom, da se „slaže“ odgovorilo je 111 ili 18,5\% ispitanika, da se „donekle slaže“ odgovorilo je 118 ili 19,6\% ispitanika, te da se „ne slaže“" odgovorilo je 80 ili 13,3\% ispitanika. Odlazak mladih iz BiH ostavlja za sobom posljedice u vidu razdvajanja društva, prijateljstava, odlazak osoba od povjerenja, oslonaca i slično. Kao manifestacija takve pojave, mladi koji ostaju u BiH sve više padaju u agoniju bez zaposlenja, bez mogućnosti druženja itd. Često se može čuti izreka kod mladih, ,pa svi su otišli, moji su svi vani, ja u ovome gradu više nikoga nemam..." itd. Kao posljedica toga, mladi se okreću upotrebi alkohola, droge ili kocke. Veliki broj je napuštenih objekata, praznih kuća koje su nerijetko meta pljačkaša gdje time podižu stopu kriminaliteta u društvu. Nažalost, posljedica koja već „kuca na vrata“ je povećana stopa socijalno-patoloških oblika ponašanja, ne samo kod mladih nego i kod roditelja koji ostaju sami u svojim domovima, gledajući fotografije svoje djece (na poznatim društvenim mrežama) kako žive vani.

Bosna i Hercegovina na godišnjem nivou gubi 1,5 milijardi eura uslijed odlaska mladih u inostranstvo. To je jedan je od ključnih zaključaka istraživačke studije "Troškovi emigracije mladih iz $\mathrm{BiH}$ " koju je proveo Institut za razvoj i inovacije uz podršku Westminster fondacije za demokratiju u BiH. 
Odlaskom mladih iz naše države, radne snage je sve manje, starija populacija pokriva mjesta gdje bi mladi trebali raditi, radni vijek se produžava.

\section{ZAKLJUČAK}

- Rezultati istraživanja su pokazali da mladi napuštaju Bosnu i Hercegovinu zbog nemogućnosti pronalska zaposlenja - tako se izjasnilo $74,3 \%$ ispitanika.

- Istraživanje je pokazalo da bi se $97,1 \%$ ispitanika željelo obrazovati van Bosne i Hercegovine radi kvalitetnijeg obrazovnog sistema $\mathrm{u}$ inostranstvu.

- Najveći broj odgovora ispitanika se vezuje za oblast neuređenosti političko-pravnog sistema u Bosni i Hercegovini, kao najčešći razlog odlaska mladih. Nefunkcionalan političko-pravni sistem mlade deprimira i gura na marginu zbivanja, a kada dođu na marginu društva, tada prelaze granice $\mathrm{i}$ odlaze $\mathrm{u}$ druge države tražiti bolje uslove za egzistenciju.

- Mladi odlaze iz BiH zbog korupcije i nepotizma, ne mogu pronaći adekvatan posao ukoliko nisu u nekoj od političkih stranaka. Istraživanje je pokazalo da se dvije trećine mladih nalaze u sličnoj situaciji, gdje zbog korupcije i nepotizma svoju budućnost vide u zemljama EU.

- Zabrinjavajući postotak od 97,1\% ispitanika se izjasnilo da bi napustili $\mathrm{BiH}$ zbog općenitog nezadovoljstva životom. Visok postotak nezadovoljstva među mladim ljudima jeste manifestacija sveukupnog stanja u Bosni i Hercegovini, koja se reflektira na odlazak mladih.

- Mladi su isključeni iz socijalnog okruženja, nisu uključeni u sportske i druge klubove, a veoma su rijetko angažirani u nevladinim organizacijama.

- Istraživanje je pokazalo da ne postoje tačni Statistički podaci o stvarnom stanju odlazaka mladih osoba iz Bosne i Hercegovine.

- Saznanjima dobivenim ovim istraživanjem moguće je inicirati i donošenje zakonskih i podzakonskih normativa, kako bi se mijenjali uticaji na kvaltetu života mladih osoba. 
- Istraživanjem se došlo do socijalno-ekonomskih posljedica migracija mladih osoba u Bosni i Hercegovini koji se manifestiraju kroz gubitak radne snage, smanjen broj uplaćenih doprinosa, kontinuirano zaduživanje BiH kod MMF-a (ogromni administrativni aparat i slično). Procjene govore da ćemo, za dvadeset godina, postati zemlja starih osoba za koje neće imati ko raditi i obezbjeđivati isplate penzija. Smanjit će se nivo potrošnje što će se direktno odraziti na ekonomsku budućnost zemlje. Odlazak ili „odliv mozgova“ - stručni i obrazovani mladi odlaze van $\mathrm{BiH}$, kao posljedicu imamo deficit obrazovnog kadra, posebno u zdravstvenom sektoru.

- Istraživanje predstavlja obimnu teorijsku podlogu i skup informacija za stručne radnike ali i privredne i političke subjekte i skup iskustava drugih, koji se susreću s problemom migracija, na osnovu čega bi profesionalci i institucije Bosne i Hercegovine mogli razviti svoje koncepcije rada s mladima, radeći na uzrocima odlaska što će prvo donijeti kratkoročne, a onda posljedično i dugoročne efekte..

- Predmetno istraživanje je posebno značajno, s obzirom da se pretpostavlja, da će se socio-ekonomska situacija u Bosni i Hercegovini pogoršati s obzirom na negativan uticaj zdravstveno-epidemiološke krize izazvane Covidom-19. Otuda se očekuje porast nezaposlenosti, posebno mladih, što će još značajnije aktualizirati njihov odlazak iz Bosne i Hercegovine.

"Lift koji vodi do uspjeha je u kvaru, ali stepenice su uvijek dostupne".

Zig Zigler

\section{LITERATURA}

Agencija za statistiku BiH, Prezentacija analize stanja stanovništva i projekcija stanovništva za period 2020-2070. u Bosni i Hercegovini, http://www.bhas.ba/News/Read/42. Pristup 21.12. 2020.

Biljan-August, M. i sar., (2009) Uporaba statistike u ekonomiji, Rijeka: Sveučilište u Rijeci, Ekonomski fakultet.

Causes and effects of human migration. Khan Academy. Dostupno na: https:/www.khanacademy.org/humanities/world-history/medievaltimes/migration/a/migration-focus-block . Pristup 4. 12. 2021 
Čičić, M. et. al. (2019) Studija o emigracijama Bosne i Hercegovine, Preuzeto sa

https://publications.anubih.ba/bitstream/handle/123456789/711/Studija\% 20o\%20emigracijama\%20BOSNA\%20I\%20HERCEGOVINA.pdf?seque nce $=1$ \&isAllowed=y. Pristup 8. 12. 2021.

Domazet, A. et. al. (2020) Održivost emigracija iz Bosne i Hercegovine, file://C:/Users/comp/Downloads/16523.pdf. Pristup 19. 11. 2021.

Graovac, Matassi, V. (2005) Starenje stanovništva u Hrvatskoj i u europskim zemljama, 3. hrvatski geografski kongres, Zbornik radova (ur. A. Toskić), Hrvatsko geografsko društvo, 288-297.

Institut za razvoj mladih KULT (2021) Istraživanje o položaju mladih u BiH, Sarajevo.

Klaić, B. (1974) Veliki rječnik stranih riječi, Zora, Zagreb.

Koronavirusna bolest (COVID-19), (https://www.who.int/healthtopics/coronavirus\#tab=tab_1). Prostup 20. 12. 2019.

Kuti, S. (2012) Koncepti transnacionalnih socijalnih prostora i polja $u$ istraživanju migracijskih i postmigracijskih procesa, Migracijske i etničke teme, 28 (2): 119 - 141. Zagreb.

Masovni odlazak mladih iz BiH: potraga za poslom ili bijeg od stvarnosti" Centar za izborne studije i njemačka fondacija „Heinrich Böll". https://cisbih.ba/2017/08/16/analiza-masovni-odlazak-mladih-iz-bihpotraga-za-poslom-ili-bijeg-od-stvarnosti/ Pristup 19. 10. 2020.

Mikac, R., Dragović, F., (2017) Masovne migracije: izazovi, posljedice i put naprijed, 132, Forum za sigurnosne studije god. 1, br. 1 .

Papić, Ž., Fondacija za socijalno uključivanje i Inicijativa za bolju i humaniju inkluziju: Niko ne smije biti isključen, https://www.klix.ba/biznis/fondacija-za-socijalno-ukljucivanje-iinicijativa-za-bolju-i-humaniju-inkluziju-niko-ne-smije-bitiiskljucen/200907088. Pristup 9. 9. 2020.

Popović-Ćitić, B. i Zunić-Pavlović, V. (2005) Prevencija prestupništva dece $i$ omladine, Ministarstvo prosvete i sporta Republike Srbije i Pedagoško društvo Srbije. Beograd.

Soldo, V. (2019) Zemlja staraca i sirotinje, DW, Gospodarstvo, https://www.dw.com/hr/zemlja-staraca-i-sirotinje/a-48614561. Pristup 11. 11. 2020. 
Strategija razvoja Federacije $\mathrm{BiH}$ 2010-2020. Federalni zavod za programiranje razvoja Sarajevo, 2010. godine „Ekonomski institut“ d.d. Tuzla.

Svjetski gospodarski forum iznio preporuke za globalni oporavak gospodarstava i društava nakon Covid-19 pandemije, http://konkurentnost.hr/svjetski-gospodarski-forum-iznio-preporuke-zaglobalni-oporavak-gospodarstava-i-drustava-nakon-Covid-19-pandemije/ Pristup 18. 10. 2021.

Šarić H., Drndić A., Andelija A., (2021) Devijantna ponašanja migranata $u$ Bosni $i$ Hercegovini, Zbornik radova sa naučne konferencije sa međunarodnim učešćem pod nazivom "Migracije u savremenom dobu uzroci i posljedice", 23. i 24. oktobar, 2020. godine, Islamski pedagoški fakultet, Univerzitet u Bihaću.

Šteta je golema, visoko obrazovanje je jako skupo, a onda mladi čovjek ode u drugu zemlju, https://www.moj-posao.net/CestaPitanja/Opis/74547/Mladi-odlaze-a-posljedice-cemo-osjetiti-2030godine/2/, Pristup 11. 11. 2020.

Troskot, Z. i sur. (2019) Ključne odrednice iseljavanja visokokvalificiranog stanovništva: Slučaj Hrvatske s komparativnim osvrtom na nove članice EU. Pravni fakultet Sveučilišta u Zagrebu.

UNICEF: Strategija socijalnog uključivanja Federacije Bosne i Hercegovine $\mathrm{za}$ period 2021-2027.

https://www.unicef.org/bih/izvje\%C5\%A1taji/strategije-socijalnoguklju\%C4\%8Divanja. Pristup 21. 1. 2021.

Unija za održivi povratak i integracije u Bosni i Hercegovini, http://www.uzopibih.com.ba/ Pristup 22. 3. 2020.

Vidanović, I., (2006) Rečnik socijalnog rada, Tiro-erc, Beograd.

Poduzetnice, (2019) Zašto mladi odlaze iz BIH i zemalja regiona? https://poduzetnice.ba/zasto-mladi-odlaze-iz-bih-i-zemalja-iz-regiona/. Pristup 22. 3. 2020.

Zakon o mladima FBiH, Službene novine FBiH br. 36/10. 
Hariz Šarić, PhD

University of Tuzla

Faculty of Philosophy

barizsario@unitz.ba

Adisa Delić, $\mathrm{PhD}$

University of Tuzla

Faculty of Economics

adisa.deli@unitz.ba

\section{SOCIO-ECONOMIC CAUSES AND CONSEQUENCES OF YOUTH LEAVING BOSNIA AND HERZEGOVINA}

\section{ABSTRACT}

The research on "Socio-economic consequences of young people leaving Bosnia and Herzegovina" aimed to locate, analyze and determine the reasons, motives and reasons for leaving their homeland and going to other destinations on the planet, focusing on the socio-economic consequences of these departures. The authors focus on the analysis and interpretation of theoretical and empirical knowledge about the consequences caused by the departure of young people from Bosnia and Herzegovina.

Starting from the multidimensionality of the problem of young people leaving Bosnia and Herregovina, which requires the identification of factors at the individual, family and social level and which contribute to this phenomenon, the research focuses on individual, endogenous and institutional factors that cause young people to leave Bosnia and Herzegovina. the consequences that the departure of young people brings with it.

The following methods and techniques were used in the research process: content analysis, questionnaire, interview, case study, survey and statistical method. A stratified sample was used for the sample, taking into account the proportional and territorial representation of young people. The research included 3000 young people who were from 18 to 29 years old in the research period.

The research conducted in Bosnia and Herzegovina in the period 2019 and 2020, showed that there are several reasons, factors and causes why young people leave BiH 
and that young people, aged 18 to 29, are represented by 69\% of the total the number of those leaving, while $31 \%$ belong to other age groups.

Based on the obtained results, we advocated for the implication of considering the negative effects of social factors on the socio-economic causes of young people leaving Bosnia and Herzegovina.

Key words: socio-economic causes, socio-economic consequences, youth, factors, 
الأستاذ الدكتور هارز شارتش

جامعة توزلا

كلية الفلسفة

hariz.saric@unitz.ba الأستاذة الدكتورة أديسة ديليتش

جامعة توزلا

الكلية الاقتصادية

adisa.delic@unitz.ba

\section{الدوافع الاجتماعية والاقتصادية وراء ارتحال الشباب من البوسنة والهرسك وعواقبها}

\section{الخلاصة}

تهدف دراسة موضوع الدوافع الاجتماعية والاقتصادية وراء ارتحال الشباب من البوسنة

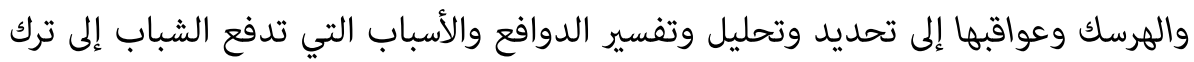

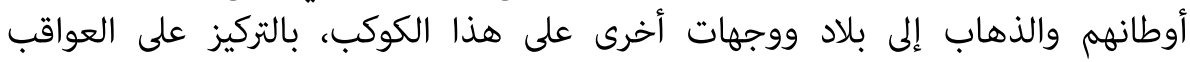

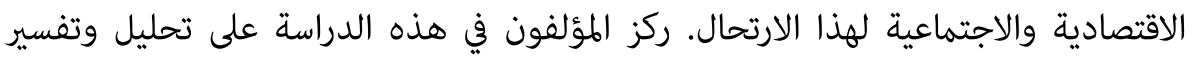

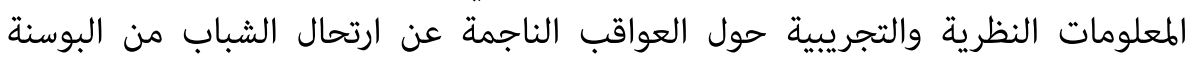
والهرسك.

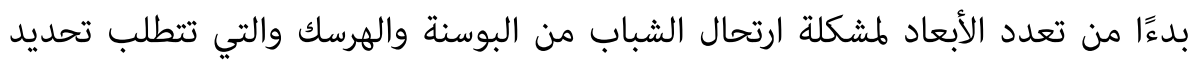

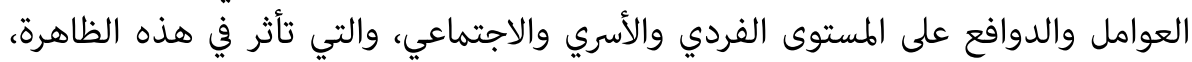

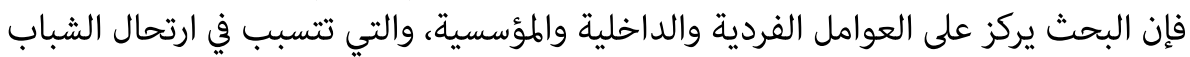
ومغادرتهم للبوسنة والهرسك، وما يترتب على ذلك العامل من عواقب الفت اجتماعية واقتصادية. تم استخدام الأساليب والتقنيات التالية في عملية البحث: تحليل المحتوى، الاستبيان، المقابلة،

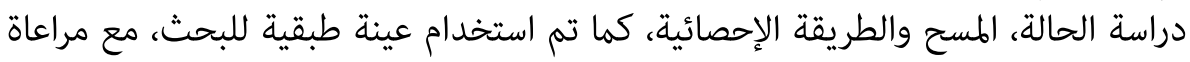

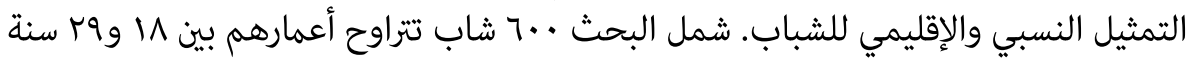
خلال فترة الدراسة والاستقصاء.

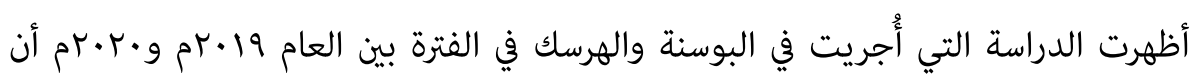

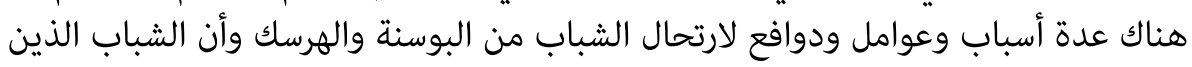




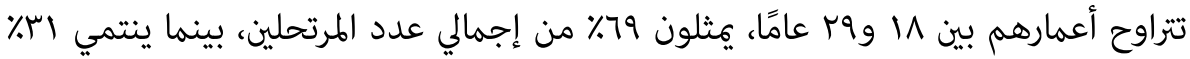

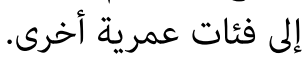

بناءً على النتائج التي تم الحصول عليها، أولينا اهتماماً بما ينطوي عليه النظر في الآثار السلبية

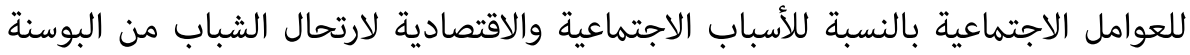
والهرسك.

الكلمات المفتاحية: الدوافع الاجتماعية والاقتصادية، العواقب الاجتماعية والاقتصادية،

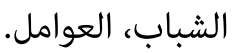

